\title{
The evidence for natural therapeutics as potential anti-scarring agents in burn- related scarring
}

\author{
M. Mehta ${ }^{1}$, O. A. Branford ${ }^{2}$ and K. J. Rolfe ${ }^{1 *}$
}

\begin{abstract}
Though survival rate following severe thermal injuries has improved, the incidence and treatment of scarring have not improved at the same speed. This review discusses the formation of scars and in particular the formation of hypertrophic scars. Further, though there is as yet no gold standard treatment for the prevention or treatment of scarring, a brief overview is included. A number of natural therapeutics have shown beneficial effects both in vivo and in vitro with the potential of becoming clinical therapeutics in the future. These natural therapeutics include both plant-based products such as resveratrol, quercetin and epigallocatechin gallate as examples and includes the non-plant-based therapeutic honey. The review also includes potential mechanism of action for the therapeutics, any recorded adverse events and current administration of the therapeutics used. This review discusses a number of potential 'treatments' that may reduce or even prevent scarring particularly hypertrophic scarring, which is associated with thermal injuries without compromising wound repair.
\end{abstract}

Keywords: Burns, Hypertrophic scar, Natural therapeutics, Wound healing

\section{Background}

A burn is defined by the World Health Organisation (WHO) as 'an injury to the skin or other organic tissue primarily caused by heat or due to radiation, radioactivity, electricity, friction or contact with chemicals' [1]. It has been estimated that annually, there are 486,000 burn injuries in the USA that required medical attention with 40,000 requiring hospitalisation [2], with a global incidence in 2004 of approximately 11 million burn injuries requiring medical attention [3]. Non-fatal burns are one of the leading causes of disability in low- to middle-income countries [3]. Advances in medical treatment means that survival following extensive burns has improved over recent years though the incidence, treatment and prevention of scarring from thermal injuries has not improved over the same time frame [4].

\footnotetext{
* Correspondence: krolfe@bcom.ac.uk

${ }^{1}$ British College of Osteopathic Medicine (BCOM), Finchley Road, London NW3 5HR, UK

Full list of author information is available at the end of the article
}

\section{Review}

\section{Hypertrophic scars}

Hypertrophic scars are defined as visible raised scars which do not spread beyond the original injury margins. Hypertrophic scars are characterised by proliferation of the dermal tissue, excessive deposition of fibroblastderived extracellular matrix (ECM) over a prolonged period of time and persistent inflammation and fibrosis [5]. Hypertrophic scars primarily contain collagen type III orientated parallel to the epidermal surface with abundant collagen nodules [6]. This structural realignment results in contracture, low tensile strength and raised scars.

The incidence of hypertrophic scars after a burn remains unclear, with estimates ranging from $26 \%$ to $75 \%$ depending on age, ethnicity and if healing was spontaneous or through surgical means (for example, skin grafting) [7-12].

Apart from the aesthetic problems, patients often complain of itching, redness and hard nodular scar tissue often with abnormal sensation. Hypertrophic scars following thermal injury are often associated with 
contractures, which can result in functional loss especially over joints such as in the hand [13].

\section{Scar formation}

Wound healing is an inherent process which aims to restore the integrity of the skin as rapidly as possible. Wound healing is divided into four stages: haemostasis, inflammation, proliferation and tissue remodelling. Within these four stages, which often overlap, there are numerous interactions between fibrotic and anti-fibrotic growth factors, cells, ECM components and numerous enzymes [14].

Fibroblasts derived from hypertrophic scars have demonstrated an altered phenotype compared to fibroblasts derived from normal scars and fibroblasts derived from uninjured tissue $[6,15]$. Fibroblasts derived from hypertrophic scars have demonstrated both an increased expression of the pro-fibrotic cytokine, transforming growth factor beta 1 (TGF- $\beta 1$ ), and a prolonged expression of the associated TGF- $\beta$ receptors (Fig. 1) $[16,17]$.
Further, there appears to be an alteration in TGF- $\beta$ signalling (via increased phosphorylation of the receptor Smad proteins) in hypertrophic-derived fibroblasts and a decreased expression of the inhibitory Smad 7 in hypertrophic scar-derived fibroblasts [18]. Studies have indicated that ectopic expression of Smad 7 prevents collagen contraction in both normal and hypertrophic scar-derived fibroblasts (FPCL: fibroblast-populated collagen lattice: model for contraction) [19].

A mouse model which lacked the receptor Smad, Smad 3, showed improved wound healing [20]. Conversely, exogenous Smad 3 (via an adenovirus-containing Smad 3 cDNA) in a rabbit dermal ulcer model showed increased granulation tissue and re-epithelisation [21]. Sumiyoshi and colleagues suggested that the differences in outcome may be that the adenovirus-containing Smad targeted mainly fibroblasts $[21,22]$, whereas in the mouse model lacking Smad 3, the deficiency was found in fibroblasts, keratinocytes and inflammatory cells.

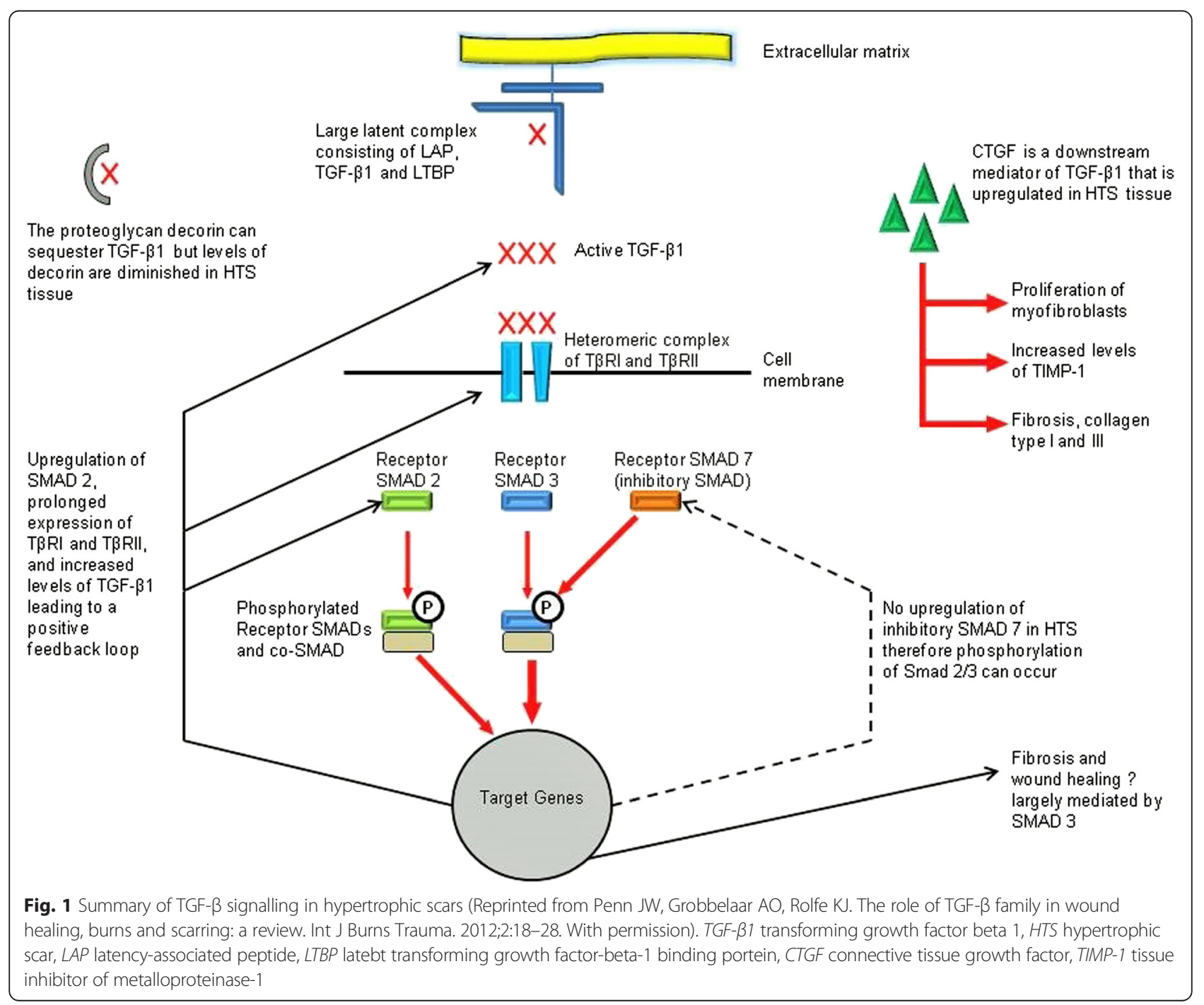


Decorin, a proteoglycan found in the dermal ECM, binds and regulates TGF- $\beta 1$ and plays a role in collagen fibrillinogenesis. Decorin has been shown to be diminished in hypertrophic scars [23]. Zhang and his colleagues demonstrated that decorin inhibited both basal and TGF- $\beta$ induced contraction in FPCL in normal and hypertrophic derived fibroblasts [24].

Linge et al. demonstrated that fibroblasts derived from hypertrophic scars failed to undergo apoptosis during FPCL contraction unlike fibroblasts derived from normal scars [25]. It was determined that the hypertrophic scarderived fibroblasts were resistant to breakdown by collagenase $\mathrm{D}$ and matrix metalloproteinase-2 (MMP-2) due to excessive cross-linking of the FPCL. Linge and colleagues further found that hypertrophic scar-derived fibroblasts over-expressed tissue transglutaminase [25]. Reducing tissue transglutaminase in hypertrophic FPCL induced apoptosis on gel contraction [25]. Differences have been further identified in myofibroblasts, and these fibroblasts express alpha smooth muscle actin and are associated with wound contraction and maturation of the granulation tissue [26]. Myofibroblasts derived from hypertrophic scars appear to be less sensitive to apoptotic signals than fibroblasts derived from normal scars and express different levels of some apoptotic-related molecules [27].

Studies suggest that migrating fibrocytes, cells with a distinct cytokine and chemokine profile, may play a role in wound repair and therefore scarring [28]. Fibrocytes appear to be increased in number of healing burn wounds and were higher in hypertrophic scar than in mature scar tissue [29]. Fibrocytes from patients who have undergone thermal injury appear to differ in their paracrine effects on dermal fibroblasts by stimulating fibroblasts to proliferate, produce and contract the ECM and stimulate production of TGF- $\beta 1$ and its downstream effector connective tissue growth factor (CTGF/CCN2) [30].

Matrix metalloproteinases are involved in the breakdown of the ECM during a number of physiological processes. MMP-1 is involved in the degradation of interstitial collagens, type I, II and III. Hypertrophicderived fibroblasts appear to have reduced collagenase (MMP-1) activity [31]. Though other studies have shown an increase in expression of MMP-2 and low level of MMP-9 [32], MMP-2 has been demonstrated to effect matrix remodelling in late wound healing, degrading denatured collagen, whereas MMP-9 appears to be involved in early wound healing degrading collagen types IV and V, fibronectin and elastin [33, 34].

Evidence suggests that the immune response may play a role in scarring. Studies have suggested an abnormality in the role of Th1/Th2 paradigm after a thermal injury $[30,35]$. Studies have implicated Toll-like receptors in fibrosis with recent studies implicating increased expression of toll-like receptor 4 (TLR4) mRNA and surface receptors implicating the Toll receptor system in potential activation of dermal fibroblast in hypertrophic scars [36].

\section{Treatment for scar}

Numerous treatments are used to reduce or prevent scarring [37, 38]. Identifying injuries, which if permitted to heal spontaneously may result in pathological scarring, is important to prevent unnecessary treatment as few treatments are without side effects [39, 40]. Compression therapy (pressure garments) has shown mixed results with a meta-analysis showing no alteration in scar scores [41], whereas a 12-year prospective study showed an overall significant improvement in scar appearance [42]. The mechanism for pressure in the reduction of scarring remains unclear though in vitro studies suggest a change in MMP, collagen and alpha smooth muscle actin expression $[43,44]$. Patient compliance is often low due to discomfort which may affect the overall clinical result, but further compression therapy has wellrecognised complications [45, 46].

Silicone gel is commonly used in the treatment or prevention of pathological scars. Results for the use of silicone gel either on its own or with compression garments remain conflicting [47], but this may in part be due to patient compliance [48]. The mechanism of action for silicone gel remains unclear though a recent study suggests that silicone gel alters the expression of TGF- $\beta 1$, platelet-derived growth factor (PDGF) and basic fibroblast growth factor (bFGF) 4 months after surgery for surgical scar revision though patient numbers were small $(n=4)$ and the original injuries were not discussed [49].

Intra-lesional corticosteroids have shown to be useful in vivo through a number of mechanisms including reduction in the inflammatory process, decrease in collagen production and fibroblast proliferation [50, 51]. Scar response rates for triamcinolone acetonide (10 to $40 \mathrm{mg} /$ $\mathrm{ml}$ ), the most common corticosteroid used for scar reduction, range from $50 \%$ to $100 \%$ with a recurrence rate of 9 $\%-53 \%$ (reviewed in [50]). However, the use of corticosteroids is often associated with pain on injection and up to $50 \%$ of patients report side effects [52].

Other treatments which are currently being studied include laser therapy [53], bleomycin, interferon, 5fluorouracil, imiquimod, methotrexate and cryotherapy [54]. However, to date, there is no effective 'gold standard' for the treatment or prevention of any scarring.

\section{Plant-based products}

A number of plants with medical properties have been studied for their effectiveness in the prevention of scarring [55]. The present review provides in vitro and/or in vivo 
evidence supporting plant-based products as potential therapeutic agents.

\section{Quercetin}

Quercetin is a flavonoid found in plants, vegetables and fruits including onions, apples and berries [56]. Quercetin has been demonstrated in vitro to have a number of biological properties including tumour suppression and anti-inflammatory, anti-oxidant properties and is anti-bacterial [57-60]. However, the metabolism of quercetin in humans may reduce its biological effects [61].

Quercetin has been shown in vitro to reduce proliferation in fibroblasts derived from keloid scars and alter intracellular signalling pathways and collagen synthesis [62-64]. Phan and colleagues demonstrated that in fibroblasts derived from keloid and hypertrophic scars, quercetin not only inhibited fibroblast proliferation by inducing cell cycle arrest but also inhibited FPCL contraction, though both cell cycle arrest and FPCL could be reversed and though resumption of contraction was slowest in the quercetin treated group [65]. Saulis and colleagues showed in a rabbit model that Mederma (active compound allium cepa, a derivative of quercetin) improved collagen organisation and therefore may have an effect on the pathophysiology of hypertrophic scars [66].

\section{Onion extract}

Onion extract in in vitro studies suggest that it may have anti-inflammatory and anti-proliferative properties on fibroblasts and mast cells and increase the expression of MMP-1 [67, 68]. Quercetin and onion extract have both been shown to induce the up-regulation of MMP-1 in vitro and in vivo [68]. MMP-1 is known to play a role in ECM remodelling and therefore quercetin and onion extract may play a role in anti-fibrotic processes.

A small $(n=16)$ randomised controlled split scar study on Asian women undergoing a Pfannenstiel's incision for caesarean section demonstrated a statistically significant reduction in scar height and symptoms at 4 and 12 weeks post-surgery in an onion extract group. However, there was no statistically significant reduction in redness or pliability of the scar over the time studied [69]. Ho et al. using a gel containing onion extract, heparin and allotonin found the gel significantly reduced the risk of scarring in 120 Chinese patients undergoing laser removal of their tattoos [70]. Wananukul et al., in a paediatric group $(n=39$; mean age 4.3 years old) who underwent a median sternotomy in a split scar experimental study (onion extract versus placebo), demonstrated that onion extract in a silicone derivative gel significantly decreased the incidence of hypertrophic scars, whereas there was no significant difference in the incidence of keloid scars [71]. Other authors have used a combination of a silicone derivative plus onion extract in patients who had undergone a median sternotomy $(n=60)$ over a treatment period of 12 weeks. They found that itch and pain was less for the treated group, there was also an improved Vancouver Scar score in the treated group especially for pigmentation [72].

Beuth and colleagues compared hypertrophic scars treated with Contractubex (cepae extract, heparin, allantoin; treatment group) for 28 days with one intralesional corticosteroid application (control group) [73].

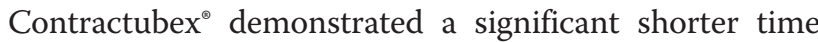
for normalisation of the scar (erythema, pruritus and consistency) compared to the corticosteroid group. Contractubex ${ }^{\circ}$ was further associated with less adverse events than corticosteroid application [73].

\section{Resveratrol}

Resveratrol is a natural plant polyphenol and phytooestrogen, present in grape skin, red wine, and peanuts $[74,75]$. Resveratrol is noted to have a number of beneficial health effects including cardio-vascular, antiinflammatory and anti-oxidant properties [74-78].

Resveratrol has been shown to reduce fibroblast cell proliferation through cell cycle arrest at G1 in fibroblasts derived from hypertrophic scars and normal skin fibroblasts and induce apoptosis [79]. Resveratrol further decreased hydroxyproline levels and down-regulated the expression of collagen type I and III mRNA [79].

Resveratrol has further shown beneficial effects in preventing surgical adhesions in an animal model [80]. Ikeda et al. demonstrated in vitro that resveratrol decreases TGF- $\beta 1$, type 1 collagen and alpha smooth muscle actin in keloid-derived fibroblasts [81]. Further, resveratrol suppressed keloid-derived fibroblast proliferation and induced apoptosis. Interestingly, resveratrol did not have the same effects on alpha smooth muscle actin or type 1 collagen in fibroblasts derived from normal scars [81].

\section{Epigallocatechin gallate (EGCG)}

EGCG is a major catechin in green tea and has a number of biological properties; it has been shown to potentially play a role in preventing fibrosis in a number of organs [82].

EGCG has been shown in FPCL to abrogate contraction stimulated by PDGF and TGF- $\beta 1$ [83, 84]. EGCG binds directly to PDGF-BB preventing the PDGF ligand binding to its receptor and therefore preventing both proliferation and FPCL contraction [83, 85]. EGCG has been shown to inhibit a number of intracellular signalling pathways and reduce expression of pro-fibrotic molecules (vascular endothelial growth factor (VEGF), TGF- $\beta 1$, CTGF) in a number of organs [86-88]. Inhibition of TGF- $\beta 1$ results in reduction of the synthesis of the ECM [84]. Interestingly, EGCG has been 
demonstrated to improve re-epithelisation in a chronic wound model and the structural stability of collagen was shown to be enhanced with EGCG $[89,90]$.

\section{Oleanolic acid (OA)}

$\mathrm{OA}$ is a naturally occurring triterpenoid compound with a number of biological properties including antiinflammatory and anti-tumour effects [91, 92]. In a rabbit ear model of hypertrophic scarring where OA was applied daily for 22 days, it was found to significantly inhibit hypertrophic scarring with a corresponding reduction in TGF- $\beta 1$ and collagen type I and III and increase levels of MMP-1 [93]. Zhang et al. also used the rabbit ear model to study $\mathrm{OA}$ and repeated the observation that $\mathrm{OA}$ reduced the incidence of hypertrophic type scars [94]. They found that TGF- $\beta 1$, MMP-1, TIMP-1 and collagen I and III were notably decreased though the number of apoptotic cells and mRNA expression of MMP-2, caspase-3 and caspase- 9 were increased in the scar tissue [94].

\section{Curcumin}

Curcumin, a polyphenol, has been shown to induce apoptosis in a number of cell lines [95-97]. Curcumin has been shown in a rat wound healing model to increase contraction and reduce wound healing time [98]. The wounds showed increased fibronectin and collagen expression with increased collagen maturation and crosslinking increasing the wounds tensile strength after treating with curcumin for 12 days $(200 \mu \mathrm{l}$ at a concentration of $40 \mathrm{mg} / \mathrm{kg}$ body weight) [98].

Scharstuhl and colleagues showed that curcumin treatment $(>25 \mu \mathrm{M}$ for $48 \mathrm{~h}$ ) induced fibroblast apoptosis and inhibited FPCL contraction via a reactive oxygen species (ROS)-mediated process in human dermal fibroblasts in vitro [99]. They concluded that curcumin at high concentrations may be a therapeutic strategy in the reduction or prevention of hypertrophic scarring and that the process can be regulated through the modulation of heme oxygenase $(\mathrm{HO})$ molecule activity or the administration of $\mathrm{HO}$ effector molecules.

\section{Shikonin}

Shikonin is a natural naphthoquinone compound from the Chinese herb Lithospermum erythrorhizon. Shikonin has been demonstrated to have a number of molecular targets, inducing apoptosis, necrosis and necroptosis in cancer cells [100-102]. It has further been demonstrated that shikonin selectively kills cancer cells while maintaining normal cells [103]. Shikonin in cancer lines has been shown to alter a number of intracellular signalling pathways particularly those associated with apoptosis [103-105]. Fan and colleagues demonstrated that Shikonin keratinocytes did not respond to Shikonin unlike human scar-derived fibroblasts which where stimulated to undergo apoptosis [106]. Shikonin induced apoptosis by altering the expression of capsase-3, B-cell lymphoma (BCL)-2, phosphorylation of ERK1/2 and p38 [107]. Further, Shikonin down-regulates collagen (type I and III) and smooth muscle actin gene expression in scar-derived fibroblasts [107].

Normal skin fibroblasts $(n=3)$ were demonstrated to reduce TGF- $\beta 1$ induced collagen production when cultured with Shikonin. This was demonstrated to be through alteration of the TGF- $\beta 1$-SMAD intracellular signalling pathway [108]. This pathway further prevented FPCL by down-regulating alpha smooth muscle actin [108].

\section{Emodin}

Emodin is a resin derived from the Himalayan rhubarb, buckthorn and Japanese knotweed. It has been investigated for a number of therapeutic effects including asthma, arthritis and Alzheimer's disease in a number of animal models [109-112]. Emodin has been shown to alter a number of intracellular signalling pathways including nuclear factor- $\mathrm{kB}$ and phosphoinositide 3 kinase/Akt [113], which plays a role in a number of cellular processes including the cell cycle. In vitro and in vivo studies have suggested that emodin may potentially play a role in preventing fibrosis in a number of organs [113-116].

Hypertrophic scars were developed through mechanical stress in an animal model, and emodin was administered intra peritoneally $(10 \mathrm{mg} / \mathrm{kg})$. Liu demonstrated that the emodin-treated hypertrophic scar group had an improved histopathological appearance compared to the control group; however, on removal of emodin at day 14, histopathology of the scar was only minimally improved at day 28 [113]. Emodin further inhibited the inflammatory response in the hypertrophic scars (tumor necrosis factor (TNF)- $\alpha$ monocyte chemoattractant protein (MCP)-1, interleukin (IL)-6). Emodin was shown to reduce the activation of PI3K and Akt in the hypertrophic fibroblasts, but this was not reciprocated in normal fibroblasts [113].

\section{Non-plant-based therapeutics Honey}

Honey has been shown to have anti-bacterial properties through the presence of inhibines which consist of hydrogen peroxide, flavonoids, phenolic acids and other as yet unidentified substances $[117,118]$. Other nonperoxide anti-microbial factors have been identified in honey depending on the floral sources, origin and processing [119-123]. However, studies have implicated that it is not simply its anti-microbial properties that confer its effectiveness in treating wounds [124]. Honey activates various components of the immune system in vitro 
Table 1 Natural therapeutics, where they originate from, their potential mechanism of action and known adverse events, bioavailability and drug interactions

\begin{tabular}{|c|c|c|}
\hline $\begin{array}{l}\text { Natural therapeutic } \\
\text { agent }\end{array}$ & Origin & Mechanism of action(s) \\
\hline Quercetin & $\begin{array}{l}\text { Flavonoid found } \\
\text { in plants, } \\
\text { vegetables and } \\
\text { fruits }\end{array}$ & $\begin{array}{l}\text { - Blocks TGF- } \beta \text { (inhibits receptor } \\
\text { expression and SMAD2/3 nuclear } \\
\text { translocation)—in turn alters } \\
\text { collagen expression [62] } \\
\text { - Alters IGF-1 signalling (through } \\
\text { reduction in receptor and } \\
\text { intracellular signalling)—in turn } \\
\text { affects keloid fibroblast } \\
\text { proliferation [63] } \\
\text { - Reduces collagen contraction } \\
\text { [65] }\end{array}$ \\
\hline $\begin{array}{l}\text { Onion extract } \\
\text { (kaempferol, } \\
\text { Mederma }^{\oplus}, \\
\text { Contractubex }^{\oplus}, \\
\text { Cybele }^{\oplus} \text {, Erasé gel, } \\
\text { Kaloidon gel) }\end{array}$ & Onion & - Up-regulates MMP-1 [68] \\
\hline Resveratrol & $\begin{array}{l}\text { Grape skin, red } \\
\text { wine and } \\
\text { peanuts }\end{array}$ & $\begin{array}{l}\text { - Inhibits fibroblast cell growth, } \\
\text { causes cell cycle arrest and } \\
\text { induces apoptosis which result in } \\
\text { reduced collagen expression [79] } \\
\text { - Reduced TGF- } \beta 1 \text { protein in } \\
\text { keloid fibroblasts }(n=5) \text {, reduced } \\
\text { cell proliferation and induced } \\
\text { apoptosis but did not decrease } \\
\text { collagen type I, alpha smooth } \\
\text { muscle actin or heat shock } \\
\text { protein } 47 \text { in normal skin } \\
\text { fibroblasts }(n=1)[81]\end{array}$ \\
\hline
\end{tabular}

\section{Epigallocatechin Green tea} gallate
- Prevents PDGF-BB binding to its receptor and leads to prevention of proliferation and collagen gel contraction $[83,85]$

- Known to inhibit a number of intracellular signalling pathways and thereby reducing pro-fibrotic gene expression [86-88] and ECM production [84]

Administered

- In vitro $[62,63,65]$

(a)


Table 1 Natural therapeutics, where they originate from, their potential mechanism of action and known adverse events, bioavailability and drug interactions (Continued)

\begin{tabular}{|c|c|c|c|c|}
\hline Curcumin & $\begin{array}{l}\text { Rhizome of } \\
\text { Curcuma longa } \\
\text { and related } \\
\text { species. }\end{array}$ & $\begin{array}{l}\text { - Induced fibroblast apoptosis and } \\
\text { reduced collagen gel contraction } \\
\text { [99] via ROS mechanism }\end{array}$ & • In vitro (human fibroblasts) [99] & $\begin{array}{l}\text { - Poor bioavailability especially } \\
\text { after oral administration [164] } \\
\text { - Appears well tolerated up to } \\
8 \mathrm{~g} / \text { day up to } 3 \text { months }[164,165] \\
\text { - Adverse effects may change with } \\
\text { adaptations that are used to } \\
\text { improve bioavailability } \\
\text { - Chelate iron suppresses hepcidin } \\
\text { therefore potentially causing iron } \\
\text { deficiency [166] } \\
\text { - Interacts with } 5 \text {-fluorouracil and } \\
\text { vinorelbine [140, 147, 148, 156] }\end{array}$ \\
\hline Shikonin & $\begin{array}{l}\text { Chinese } \\
\text { herbRadix } \\
\text { Arnebiae }\end{array}$ & $\begin{array}{l}\text { - Induces apoptosis in fibroblasts } \\
\text { [106] } \\
\text { - Down-regulates collagen types } \\
\text { I and III and a smooth muscle } \\
\text { actin [107] } \\
\text { - Appears to induce apoptosis } \\
\text { by altering p-ERK 1/2, p-p38 and } \\
\text { caspase-3 [107] }\end{array}$ & $\begin{array}{l}\text { - In vitro (human keratinocytes, } \\
\text { skin fibroblasts) [106] } \\
\text { • In vitro (human keratinocytes, } \\
\text { human skin fibroblasts, } \\
\text { hypertrophic scar-derived } \\
\text { fibroblasts) [107] }\end{array}$ & $\begin{array}{l}\text { - Low bioavailability due to high } \\
\text { lipophilicity [167] altered through } \\
\text { the formation of a complex with } \\
\text { other proteins [150] } \\
\text { - Limited toxicity studies-one } \\
\text { animal study demonstrated that it } \\
\text { appeared safe up to } \\
\text { concentrations of } 800 \mathrm{mg} / \mathrm{kg} \text { for } \\
180 \text { days [168] }\end{array}$ \\
\hline Emodin & $\begin{array}{l}\text { Derived from the } \\
\text { Himalayan } \\
\text { rhubarb, } \\
\text { buckthorn and } \\
\text { Japanese } \\
\text { knotweed }\end{array}$ & $\begin{array}{l}\text { - Alters the intracellular pathway } \\
\text { of Pi3K and Akt but only in } \\
\text { hypertrophic scar-derived } \\
\text { fibroblasts [113] and this in turn } \\
\text { inhibited the inflammatory } \\
\text { response and improved the } \\
\text { histopathology appearance of } \\
\text { the scar [113] }\end{array}$ & $\begin{array}{l}\text { - In vivo and in vitro (mice model } \\
\text { for hypertrophic scars, emodin was } \\
\text { administered intra-peritoneally; } \\
\text { mice derived hypertrophic scarring } \\
\text { fibroblasts and normal fibroblasts) } \\
\text { [113] }\end{array}$ & - Not known as yet \\
\hline Honey & & $\begin{array}{l}\text { - Accelerates wound healing due } \\
\text { to its anti- bacterial activity, anti- } \\
\text { oxidant activity, stimulator effects } \\
\text { and anti-inflammatory effects } \\
\text { [135-137] }\end{array}$ & $\begin{array}{l}\text { - Human patients with } \\
\text { burns-honey-impregnated gauze } \\
{[135,136]}\end{array}$ & $\begin{array}{l}\text { - Stinging pain on administration, } \\
\text { local atopic reactions in paediatric } \\
\text { group [169] }\end{array}$ \\
\hline
\end{tabular}

TGF- $\beta 1$ transforming growth factor beta 1, IGF-1 insulinlike growth factor-1, MMP matrix metalloproteinase, PDGF-BB platelet-derived growth factor-BB,

$E C M$ extracellular matrix, RGCG epigallocatechin gallate, $R O S$ reactive oxygen species

and in vivo which not only activates the immune response but also tissue repair [125-129].

To date, there have been mixed results with the use of honey on wounds. Nakajima and colleagues using a mouse model and three forms of Japanese honey found that the use of honey had little benefit in wound healing [130]. Gupta and colleagues retrospectively compared the hospital records of burns patients who had been treated with either honey dressings or silver sulfadiazine dressings over a period of 5 years [131]. They found that honey enhanced healing, reduced contractures and had better overall outcome compared to silver sulfadazine [131]. Others have confirmed the beneficial effects of honey and healing time when compared to other dressings including silver sulfadazine-, film- and gauze-based dressings [132, 133]. However, silver sulfadiazine has been shown to delay healing and increase pain and infection rates and may therefore have not been the best comparator [134]. Honey's anti-inflammatory effect is proposed as the reason why honey reduces fibrosis and scarring [135-137].

\section{Adverse events, bioavailability interactions and synergistic effects}

Though considered 'natural', most of the products are synthetically manufactured; further, even some 'natural' products have been identified as causing toxicities (Table 1) [138, 139]. There have been limited toxicity studies conducted on the natural therapeutics discussed in this review, though those used in human studies appear to have mild adverse events recorded (such as honey, onion extract, quercetin; Table 1). Though there have been individuals who appear to have increased adverse events, resveratrol saw one individual in a study show grade 4 elevation of their liver function markers after 3 months treatment of $1 \mathrm{~g}$ of resveratrol daily [140]. The patient's markers returned to normal after discontinuing the medication. EGCG has also shown in some individuals to elevate liver function tests though one study concluded it was an issue with the lot [141], though a case study did identify drug-induced hepatitis with the use of a concentrated green tea extract [142]. Oleanolic acid in animal studies suggests that repeated 
oral administration can cause liver injury [138]. Oleanolic acid derivatives have been also shown to be related to fluid overload which in some individuals resulted in heart failure in patients with stage 4 chronic renal disease $(8.8 \%$ of the treated group compared to $5 \%$ of the placebo group) [139].

It has been well recognised that some herbal products can interact with medicinal drugs and reduce or prevent their effectiveness, e.g. St John's wort (Hypericum perforatum), and in some cases, alter the efficacy of medicinal drugs [143]. A number of the products discussed in this paper have also been shown to interact with other drugs including antibiotics (fluoroquinones) and chemotherapy agents [144-148].

A number of the agents have been shown to have low bioavailability (quercetin, curcumin, shikonin), and others have been suggested that oral administration may not be sufficient for therapeutic levels to be reached or indeed maintained [149]. Further, those that have low bioavailability which are then either manipulated or other proteins added this structural alteration may affect both adverse events and the actual therapeutic mechanisms $[150,151]$. To date, there remains a paucity of information in regard to the safety of some of these agents in their use as anti-scarring products.

\section{Conclusions}

In vitro and in vivo studies have shown that a number of 'natural' therapeutic agent and strategies may play a role in the future treatment of scarring, particularly hypertrophic scarring which is so intrinsically linked with burn injuries. There remains no gold standard in the treatment or prevention of scarring. It remains problematic comparing all products not just natural therapeutics in part due to the number of methodologies used to assess the effectiveness of anti-scarring therapeutics and the number of models used. Further, those that do undergo clinical trials, the variation in patients and outcome measures is immense leading to problems in comparing agents and is often undertaken once the scar has formed. There is a theoretical risk which agents that reduce or prevent scarring may in turn prevent or lengthen the wound healing process, and this has yet to be elucidated. However, it appears that there is a potential for a natural therapeutic as either a monotherapy or as an adjunct to play a role in treating or even preventing hypertrophic scarring.

\footnotetext{
Abbreviations

ECM: extracellular matrix; FPCL: fibroblast-populated collagen lattice; MMP: matrix metalloproteinase.
}

\section{Competing interests}

The authors declare they have no competing interests.

\section{Authors' contributions}

KR conceived the idea and drafted the manuscript. MM and OB participated in the design and coordination. All authors read and approved the final manuscript.

\section{Author details}

${ }^{1}$ British College of Osteopathic Medicine (BCOM), Finchley Road, London NW3 5HR, UK. ${ }^{2}$ The Royal Marsden Hospital, Fulham Rd, London SW3 6JJ, UK.

Received: 5 October 2015 Accepted: 12 April 2016

Published online: 04 May 2016

\section{References}

1. World Health Organization http://www.who.int/mediacentre/factsheets/ fs365/en/ Accessed 5th Jan 2016

2. American Burn Association. http://ameriburn.org/resources_factsheet.php accessed 9th Jul 2015

3. WHO http://www.who.int/violence_injury_prevention/other_injury/burns/ en/ Accessed 9th Jul 2015

4. Sheridan RL. Burn care: results of technical and organizational progress. JAMA. 2003;290:719-22.

5. Singer AJ, Clark RA. Cutaneous wound healing. N Engl J Med. 1999;341:738-46.

6. Gauglitz GG, Korting HC, Pavicic T, Ruzicka T, Jeschke MG. Hypertrophic Scarring and Keloids: Pathomechanisms and Current and Emerging Treatment Strategies. Mol Med. 2011;17(1-2):113-25.

7. Deitch EA, Wheelahan TM, Rose MP, Clothier J, Cotter J. Hypertrophic burn scars: analysis of variables. J Trauma. 1983;23:895-8.

8. McDonald WS, Deitch EA. Hypertrophic skin grafts in burned patients: a prospective analysis of variables. J Trauma. 1987;27:147-50.

9. Spurr ED, Shakespeare PG. Incidence of hypertrophic scarring in burninjured children. Burns. 1990;16:179-81.

10. Dedovic Z, Koupilova I, Brychta P. Time trends in incidence of hypertrophic scarring in children treated for burns. Acta Chir Plast. 1999;41(3):87-90.

11. Bombaro KM, Engrav LH, Carrougher GJ, Wiechman SA, Faucher L, Costa BA et al. What is the prevalence of hypertrophic scarring following burns? Burns. 2003;9:299-302.

12. Gangemi EN, Gregori D, Berchialla P, Zingarelli E, Cairo M, Bollero D, et al. Epidemiology and the risk factors for pathological scarring after burn wounds. Arch Facial Plast Surg. 2008;10:93-102.

13. Schneider JC, Holvanahalli R, Helm P, Goldstein R, Kowalske K. Contractures in burn injury; defining the problem. J Burn Care Res. 2006;27:508-14.

14. Tredget EE. Pathophysiology and treatment of fibroproliferative disorders following thermal injury. Ann N Y Acad Sci. 1999;888:165-82.

15. Ali SS, Hajrah NH, Ayuob NN, Moshref SS, Abuzinadah OA. Morphological and morphometric study of cultured fibroblast from treated and untreated abnormal scar. Saudi Med J. 2010;30:874-81.

16. Schmid P, Itin P, Bi C, Cox DA. Enhanced expression of transforming growth factor- beta type I and type || receptors in wound granulation tissue and hypertrophic scar. Am J Pathol. 1998;15(2):485-93.

17. Wang R, Ghahary A, Shen Q, Scott PG, Roy K, Tredget EE. Hypertrophic scar tissues and fibroblasts produce more transforming growth factor- beta 1 mRNA and protein than normal skin and cells. Wound Repair and Regen. 2000;8:128-37.

18. Xie JL, Qi SH, Pan S, Xu YB, Li TZ, Liu XS, et al. Expression of Smad proteins by normal skin fibroblasts and hypertrophic scar fibroblasts in response to transforming growth factor beta 1. Dermatol Surg. 2008;34:1216-24.

19. Kopp J, Preis E, Said H, Hafemann B, Wickert L, Gressner AM, et al. Abrogation of transforming growth factor-B signalling by SMAD 7 inhibits collagen gel contraction of human dermal fibroblasts. J Biol Chem. 2006; 22(3):21570-6.

20. Ashcroft GS, Yang X, Glick AB, Weinstein M, Letterio JL, Mizel DE, et al. Mice lacking Smad3 show accelerated wound healing and an impaired local inflammatory response. Nat Cell Biol. 1999;1(5):260-6.

21. Sumiyoshi K, Nakao A, Setoguchi Y, Okumura K, Ogawa H. Exogenous Smad3 accelerates wound healing in a rabbit derma ulcer model. J Invest Dermatol. 2004;123:229-36.

22. Setoguchi $Y$, Jaffe HA, Danel C, Cystal RG. Ex vivo and in vivo gene transfer to the skin using replication-deficient recombinant adenovirus vectors. J Invest Dermatol. 1994;102:415-21.

23. Scott PG, Dodd CM, Tredget EE, Ghahary A, Rahemtulla F. Chemical characterisation and quantification of proteoglycans in human post burn hypertrophic and mature scars. Clin Sci (London). 1996;90:417-25. 
24. Zhang Z, Garron TM, Li XJ, Liu Y, Zhang X, Li YY, et al. Recombinant human decorin inhibits TGF-beta 1 induced contraction of collagen lattice by hypertrophic scar fibroblasts. Burns. 2009;35(4):527-37.

25. Linge C, Richardson J, Vigor C, Clayton E, Hardas B, Rolfe K. Hypertrophic scars cells fail to undergo a form of apoptosis specific to contractile collagen- the role of transglutaminase. J Invest Dermatol. 2005;12:72-82.

26. Hinz B, Gabbiani G. Cell-matrix and cell-cell contacts of myofibroblasts: role in connective tissue remodeling. Thromb Haemost. 2003;90(6):993-1002.

27. Moulin V, Larochelle S, Langlois C, Thibault I, Lopez-Valle CA, Roy M. Normal skin wound and hypertrophic scar myofibroblasts have differential responses to apoptotic inductors. J Cell Physiol. 2004;198(3):350-8.

28. Yang L, Scott PG, Giuffre J, Shankowsky HA, Ghahary A, Tredget EE. Peripheral blood fibrocytes from burn patients: identification and quantification of fibrocytes in adherent cells cultured from peripheral blood mononuclear cells. Lab Invest. 2002:82:1183-92.

29. Yang L, Scott PG, Dodd C, Medina A, Jiao H, Shankowsky HA, et al. Identification of fibrocytes in post burn hypertrophic scar. Wound Repair Regen. 2005;13(4):398-404.

30. Wang J, Jiao H, Stewart TL, Shankowsky HA, Scott PG, Tredget EE. Increased TGF-beta-producing CD41 T lymphocytes in post burn patients and their potential interaction with dermal fibro-blasts in hypertrophic scarring. Wound Repair Regen. 2007;15(4):530-9.

31. Eto $H$, Suga $H$, Aoi N, Kato H, Doi K, Kuno S, et al. Therapeutic potential of fibroblast growth factor-2 for hypertrophic scars: up regulation of MMP-1 and HGF expression. Lab Invest. 2012;92:214-23.

32. Neely AN, Clendening CE, Gardner J, Greenhalgh DG, Warden GD. Gelatinase activity in keloids and hypertrophic scars. Wound Repair Regen. 1999;7(3):166-71.

33. Mauviel A. Cytokine regulation of metalloproteinase gene expression. J Cell Biochem. 1993:53:288-95.

34. Zhang Y, McCluskey K, Fuji K, Wahl LM. Differential regulation of metalloproteinase and TIMP-1 production by TNF-alpha, granulocyte macrophage CSF and IL-1 beta through prostaglandin dependent and independent mechanisms. J Immunol. 1998;161:3071-6.

35. Tredget EE, Yang L, Delehanty M, Shankowsky H, Scott PG. Polarized T helper cells Th2 cytokine production in patients with hypertrophic scar following thermal injury. J Interferon Cytokine Res. 2005;26:179-89.

36. Wang J, Hori K, Ding J, Huang Y, Kwan P, Ladak A, et al. Toll-like receptors expressed by dermal fibroblasts contribute to hypertrophic scarring. J Cell Physiol. 2011;226(5):1265-73.

37. Liuzzi F, Chadwick S, Shah M. Paediatric post-burn scar management in the UK: A national survey. Burns. 2015;41(2):252-6.

38. Sidgwick GP, McGeorge D, Bayat A. A comprehensive evidence-based review on the role of topical and dressings in the management of skin scarring. Arch Dermatol Res. 2015:307:461-77.

39. Stewart TL, Ball B, Schembri PJ, Hori K, Ding J, Shankowsky HA, et al. The use of laser Doppler imaging as a predictor of burn depth and hypertrophic scar post burn injury. J Burn Care. 2012;33(6):764-71.

40. Kwan PO, Ding J, Tredget EE. Serum decorin, IL-1 $\beta$ and TGF- $\beta$ predict hypertrophic scarring post burn. J Burn care Res. In press.

41. Anzarut A, Olson J, Singh $P$, Rowe BH, Tredget EE. The effectiveness of pressure garment therapy for the prevention of abnormal scarring after burn injury: a meta-analysis. J Plast Reconstr Aesthet Surg. 2009;62(1):77-84.

42. Engrav LH, Heimbach DM, Rivara FP, Moore ML, Wang J, Carrougher GJ, et al. 12-year within-wound study of the effectiveness of custom pressure garment therapy. Burns. 2010;36(7):975-83.

43. Ranò F, Grazianetti P, Stella M, Magliacani G, Pezzulto C, Cannas M. Release and activation of matrix metalloproteinase -9 during in vitro mechanical compression in hypertrophic scars. Arch Dermatol. 2002;138(4):475-8.

44. Costa AM, Peyrol S, Pôrto LC, Comparin JP, Foyatier JL, Desmoulière A Mechanical forces induce scar remodelling. Study in non-pressure-treated versus pressure-treated hypertrophic scars. Am J Pathol. 1999:155(5):1671-9.

45. Johnson J, Greenspan B, Gorga D, Nagler W, Goodwin C. Compliance with pressure garment use in burn rehabilitation. J Burn Care Rehab. 1994;15(2): 180-8.

46. Macintyre $L$, Baird M. Pressure garments for use in the treatment of hypertrophic scars- a review of the problems associated with their use. Burns. 2006;32(1):10-5.

47. O'Brien $L$, Jones DJ. Silicone gel sheeting for preventing and treating hypertrophic and keloid scars. Cochrane Database Syst Rev. 2013;9: CD003826.
48. So K, Umraw N, Scott J, Campbell K, Musgrave M, Cartotto R. Effects of enhanced patient education on compliance with silicone gel sheeting and burn scar outcome: a randomised prospective study. J Burn Care Rehabi. 2003:24(6):411-7.

49. Choi J, Lee EH, Park SW, Chang H. Regulation of Transforming growth factor $\beta 1$, platelet-derived growth factor, and basic fibroblast growth factor by silicone gel sheeting in early-stage scarring. Arch Plast Surg. 2015;42(1):20-7.

50. Gauglitz GG. Management of keloids and hypertrophic scars: current and emerging options. Clin Cosment Investig Dermatol. 2013;6:103-14.

51. Roques $C$, Téot $L$. The use of corticosteroids to treat keloids.: A review. Int J of Low Extrem Wounds. 2008;7(3):137-45.

52. Manuskiatti W, Fitzpatrixk RE. Treatment response of keloidal and hypertrophic sternotomy scars: comparison among intralesional corticosteroid, 5-fluorouracil, and $585 \mathrm{~nm}$ flashlamp-pumped pulse dye laser treatments. Arch Dermatol. 2002;138(9):1149-55.

53. Tredget EE, Levi B, Donelan MB. Biology and principles of scar management and burn reconstruction. Surg Clin North Am. 2014:94(4):793-815.

54. Rabello FB, Souza CD, Júnior JAF. Update on hypertrophic scar treatment. Clinics. 2014:69(8):565-573.55.

55. Ye Q, Wang S-J, Chen J-Y, Rahman K, Hai-Liang X, Zhang H. Medicinal plants for the treatment of hypertrophic scars. Evid Based Complement Alternat Med. 2015;2015:101340.

56. Ross JA, Kasum CM. Dietary flavonoids: bioavailability, metabolic effects, and safety. Annu Rev Nutr. 2002;22:19-34.

57. Bors W, Heller W, Michel C, Saran M. Flavonoids as antioxidants: Determination of radical-scavenging efficiencies. Methods Enzymol. 1990; 186:343-55.

58. Lamson DW, Brignall MS. Antioxidants and cancer, part 3: Quercetin. Altern Med Rev. 2000;5:196-208.

59. Prior RL. Fruits and vegetables in the prevention of cellular oxidative damage. Am J Clin Nutr. 2003;78:570-8S.

60. Williams RJ, Spencer JP, Rice-Evans C. Flavonoids: antioxidants or signalling molecules? Free Radic Biol Med. 2004;36(7):838-49.

61. Barnes S, Prasain J, D'Alessandro T, Arabshahi A, Botting N, Lila MA, et al. The metabolism and analysis of isoflavones and other dietary polyphenols in foods and biological systems. Food Function. 2011;2(5):235.

62. Phan TT, Lim IJ, Chan SY, Tan EK, Lee ST, Longaker MT. Suppression of transforming growth factor beta/smad signalling in keloid derived fibroblasts by querectin; implications for the treatment of excessive scars. Trauma. 2004;57(5):1032-7.

63. Phan TT, Sun L, Tran E, Nguyen TT, Chan SY, Lee ST, et al. Suppression of insulin like growth factor signalling pathway and collagen expression in keloid derived fibroblasts by quercetin: its therapeutic potential use in the treatment and/or prevention of keloids. Br J Dermatol. 2003;148(3):544-52.

64. Long $X$, Zeng $X$, Zhang FQ. Influence of quercetin and xray on collagen synthesis of cultured human keloid fibroblasts. Chin Med Sci J. 2006;21(3): 179-83.

65. Phan TT, Sun L, Bay BH, Chan SY, Lee ST. Dietary compounds inhibit proliferation and contraction of keloid and hypertrophic scar derived fibroblasts in vitro: therapeutic implications for excessive scarring. J Trauma. 2003:54(6):1212-24.

66. Saulis AS, Mogford JH, Mustoe TA. Effect of Mederma on hypertrophic scarring in the rabbit ear model. Plast Recontr Surg. 2002:110(1):177-83.

67. Augusti T. Therapeutic values of onion (Allium cepa L.) and garlic (Allium sativum L.). Indian J Exp Biol. 1996;34(7):634-40.

68. Cho J-W, Cho S-Y, Lee S-R, Lee K-S. Onion extract and quercetin induce matrix metalloproteinase -1 in vitro and in vivo. Int J Mol Med. 2010;25:347-52.

69. Chanprapaph K, Tanrattanakorn S, Wattanakrai P, et al. Effectiveness of onion extract gel on surgical scars in Asians. Dermatol Res Pract. 2012;2012: 212945.

70. Ho WS, Ying SY, Chan PC, Chan HH. Use of onion extract, heparin, allantoin gel in prevention of scarring in Chinese patients having laser removal of tattoos: A prospective randomized controlled trial. Dermatol Surg. 2006; 32(7):891-6

71. Wananukul S, Chatpreodprai S, Peongsujarit D, Lertsapcharoen P. A prospective placebo-controlled study on the efficacy of onion extract in silicone derivative gel for the prevention of hypertrophic scar and keloid in median sternotomy wound in pediatric patients. J Med Assoc Thai. 2013; 96(11):1428-33.

72. Jenwitheesuk K, Surakunprapha P, Jenwitheesuk K, Kuptamond C, Prathanee $\mathrm{S}$, Intanoo W. Role of silicone derivative plus onion extract gel in presternal 
hypertrophic scar protection: a prospective randomized, double blinded, controlled trial. Int Wound J. 2012;9:397-402.

73. Beuth J, Hunzelmann N, van Leendert R, Basten R, Noehle M, Schenider B. Safety and Efficacy of Local Administration of Contractubex ${ }^{\circledR}$ to Hypertrophic Scars in Comparison to Corticosteroid Treatment. Results of a Multicenter, Comparative Epidemiological Cohort Study in Germany. In vivo. 2006;20:277-84

74. George J, Singh M, Srivastava AK, Bhui K, Roy P, Chaturvedi PK, et al. Resveratrol and Black Tea Polyphenol Combination Synergistically Suppress Mouse Skin Tumors Growth by Inhibition of Activated MAPKs and p53. PLoS ONE. 2011;6:e23395.

75. Hiroto Y, Tadokoro K, Tsuda T, Nakazono E, Ohnaka K, Takayanagi R, et al. Resveratrol, a phytoestrogen found in red wine, down-regulates protein $\mathrm{S}$ expression in HepG2 cells. Thrombo Res. 2011;127:e1-7.

76. Olson ER, Naugle JE, Zhang X, Bomser JA, Meszaros JG. Inhibition of cardiac fibroblast proliferation and myofibroblast differentiation by resveratrol. Am J Physiol Heart Circ Physiol. 2005;288(3):1131-8.

77. Glehr M, Fritsch-Breisach M, Lohberger B, Walzer SM, Moazedi-Fuerst F, Rinner B, et al. Influence of resveratrol on rheumatoid fibroblast-like synoviocytes analysed with gene chip transcription. Phytomedicine. 2013; 20(3-4):310-8

78. Yao J, Wang JY, Liu L, Li YX, Xun AY, Zeng WS, et al. Anti-oxidant effects of resveratrol on mice with DSS-induced ulcerative colitis. Arch Med Res. 2010; 41(4):288-94.

79. Zeng G, Zhong F, Luo JL, Zhang P. Resveratrol mediated reduction of collagen by inhibiting proliferation and producing apoptosis in human hypertrophic scar fibroblasts. Biosci Biotechnol Biochem. 2013;77(12):2389-96.

80. Sogutlu G, Karabulut AB, Ara C, Cinpolat O, Isik B, Piskin T, et al. The effect of resveratrol on surgery induced peritoneal adhesions in an experimental model. Cell Biochem Funct. 2007:25(2):217-20.

81. Ikeda K, Torigoe T, Matsumoto Y, Fujita T, Sato N, Yotsuyanag T. Resveratrol inhibits fibrogenesis and induces apoptosis in keloid fibroblasts. Wound Repair Regen. 2013;21:616-23.

82. Branford OA, Grobbelaar AO, Rolfe KJ. Epigallocatechin-3-gallate (EGCG), a constituent of green tea and its anti-fibrotic effect. In Tea Consumption and Health Nova. 153-166.

83. Suzuki Y, Hattori S, Isemura M. Epigallocatechin-3-O-gallate inhibits fibroblast contraction of floating collagen gel: Interaction between epigallocatechin-3-O-gallate and platelet derived growth factor. Biosci Biotechnol Biochem. 2004;68:1817-20.

84. Klass BR, Branford OA, Grobbelaar AO, Rolfe KJ. The effect of epigallocatechin-3-gallate, a constituent of green tea, on transforming growth factor-beta1-stimulated wound contraction. Wound Repair Regen. 2010;18(1):80-8.

85. Weber AA, Neuhaus T, Skach RA, Hatcheller J, Ahn HY, Schrör K, et al. Mechanisms of the inhibitory effects of epigalocatechin-3 gallate on platelet -derived growth factor-BB induced cell signalling and mitogenesis. FASEB J. 2004;18:128-30

86. Cai Y, Yu SS, Chen $\Pi$, Gao S, Geng B, Yu Y, et al. EGCG inhibits CTGF expression via blocking NF- $\mathrm{KB}$ activation in cardiac fibroblast. Phytomedicine. 2013;20(2):106-13.

87. Wang CY, Deng YT, Huang SY, Liu CM, Chang HH, Wong MY. Epigallocatechin-3-gallate inhibits lysophosphatidic acid-stimulated connective tissue growth factor via JNK and Smad3 suppression in human gingival fibroblasts. J Formos Med Assoc. 2014;223(1):50-5.

88. Moyle CW, Cerezo AB, Winterborne MS, Hollands WJ, Alexeev Y, Needs PW, et al. Potent inhibition of VEGFR-2 activation by tight binding of green tea epigallocatechin gallate and apple procyanidins to VEGF: relevance to angiogenesis. Mol Nutr Food Res. 2015;59(3):401-12.

89. Kim H, Kawazoe T, Han DW, Matsumara K, Suzuki S, Tsutsumi S, et al. Enhanced wound healing by an epigallocatechin gallate incorporated collagen sponge in diabetic mice. Wound Repair Regen. 2008;16:714-20.

90. Goo HC, Hwang YS, Choi YR, Cho HN, Suh H. Development of collagenaseresistant collagen and its interaction with adult human dermal fibroblasts. Biomaterials. 2003;24:5099-113.

91. Yang EJ, Lee W, Ku SK, Song KS, Bae JS. Anti-inflammatory activities of oleanolic acid on HMGB1 activated HUVECs. Food Chem Toxicol. 2012;50(5):1288-94.

92. Chakravarti B, Maurya R, Siddiqui JA, Bid HK, Rajendran SM, Yadav PP, et al. In vitro anti-breast cancer activity of ethanolic extract of Wrightiato mentosa: role of pro-apoptotic effects of oleanolic acid and urosolic acid. J Ethnopharmacol. 2012;142(1):72-9.
93. Wei $Y$, Yan XQ, Ma L, Wu JG, Zhang H, Qin LP. Oleanolic acid inhibits hypertrophic scarring in the rabbit ear model. Clin Exp Dermatol. 2011;36(5): 528-33.

94. Zhang $H$, Zhang $Y$, Jiang YP, Zhang LK, Peng C, He K, et al. Curative effects of oleanolic acid on formed hypertrophic scars in the rabbit ear model. Evid Based Complement Alternat Med. 2012;2012:2012837581.

95. Atsumi T, Murakami Y, Shibuya K, Tonosaki K, Fujisawa S. Induction of cytotoxicity and apoptosis and inhibition of cyclooxygenase-2 gene expression, by curcumin and its analogue, alphadiisoeugenol. Anticancer Res. 2005;25:4029-36.

96. Chan WH, Wu HY, Chang WH. Dosage effects of curcumin on cell death types in a human osteoblast cell line. Food Chem Toxicol. 2006;44:1362-71.

97. Dujic J, Kippenberger S, Hoffmann S, Ramirez-Bosca A, Miguel J, Diaz-Alperi $J$, et al. Low concentrations of curcumin induce growth arrest and apoptosis in skin keratinocytes only in combination with UVA or visible light. J Invest Dermatol. 2007;127:1992-2000

98. Panchatcharam M, Miriyala S, Gayathr VS, Suguna L. Curcumin improves wound healing by modulating collagen and decreasing reactive oxygen species. Mol Cell Biochem. 2006;290:87-96.

99. Scharstuhl A, Mutsaers HAM, Pennings SW, Szarek WA, Russel FG, Wagener FA. Curcumin-induced fibroblast apoptosis and in vitro wound contraction are regulated by antioxidants and heme oxygenase: implications for scar formation. J Cell Mol Med. 2009;13(4):712-25.

100. Wang R, Yin R, Zhou W, Xu D, Li S. Shikonin and its derivatives: a patent review. Expert Opin Ther Pat. 2012;22:977-97.

101. Wu Y, Fabritius MIC. Chemotherapeutic sensitization by endoplasmic reticulum stress: increasing the efficacy of taxane against prostate cancer. Cancer Biol Ther. 2009:8:146-52.

102. Yang JT, Li ZL, Wu JY, Lu FJ, Chen CH. An oxidative stress mechanism of shikonin in human glioma cells. PLoS One. 2014;9:e94180.

103. Chang IC, Huang YJ, Chiang CW, Yeh LS. Shikonin induces apoptosis through reactive oxygen species/extracellular signal- regulated kinase pathway in osteosarcoma cells. Biol Pharm Bull. 2010;33:816-24.

104. Hashimoto S, Xu M, Masuda T, Aiuchi S, Nakajo J, Cao M, et al. Betahydroxyisoovaleryishikonin inhibits the cell growth of various cancer cell lines and induces apoptosis in leukemia HL-60cells through a mechanism different from those of Fas and etoposide. J Biochem. 1999;125:17-23.

105. Gao D, Hiromura M, Yasui H, Sakurai H. Direct reaction between Shikonin and thiols induces apoptosis in HL60 cells. Biol Pharm. 2002;25:827-82.

106. Fan C, Xie Y, Dong Y, Su Y, Upton Z. Investigating the potential of Shikonin as a novel hypertrophic scar treatment. J Biomed Sci. 2015;22:70.

107. Xie Y, Fan C, Dong Y, Lynam E, Leavesley DI, Li K, et al. Functional and mechanistic investigation of Shikonin in scarring. Chemico-Bio Interact. 2015;228:18-27.

108. Fan C, Dong Y, Xie Y, Su Y, Zhang X, Leavesley D, et al. Shikonin reduces TGF- $\beta 1$ - induced collagen production and contraction in hypertrophic scar derived fibroblasts. Int J Mole Med. 2015;36:985-91.

109. Wang T, Zhong XG, Li YH, Zhang SJ, Gao YS, et al. Protective effect of emodin against airway inflammation in the ovlbumin-induced mouse model. Chin J Integr Med. 2015;21:431-7.

110. Zhu X, Zeng K, Qiu Y, Yan F, Lin C. Therapeutic effect of emodin on collagen-induced arthritis in mice. Inflammation. 2013;36:1253-9.

111. Sun YP, Liu JP. Blockade of emodin on amyloid- $\beta$ 26-35-induced neurotoxicity in AßPP/PS1 mice and PC12 cells through activation of the class III phosphatidylinositol 3-kinase/Beclin-1/B cells lymphoma 2 pathway. Planta Med. 2015:81:108-15.

112. Shirmali D, Shanmugam MK, Kumar AP, Zhang J, Tan BK, Sethi G. Targeted abrogation of diverse signal transduction cascades by emodin for the treatment of inflammatory disorders and cancer. Cancer Lett. 2013;341:139-49.

113. Liu C. Inhibition of mechanical stress-induced hypertrophic scar inflammation by emodin. Molec Med Reports. 2015;11:4087-92.

114. Hu Q, Noor M, Wong YF, Hylands PJ, Simmonds MS, Xu Q, et al. In vitro anti fibrotic activities of herbal compounds and herbs. Nephrol Dial Transplant. 2009:24:3033-41.

115. Chen XH, Sun RS, Hu JM, Mo ZF, Yang ZF, Jin GY, et al. Inhibitory effect of emodin on bleomycin-induced pulmonary fibrosis in mice. Clin Exp Pharmacol Physiol. 2009;36:146-53.

116. Dong MX, Jia Y, Zhang YB, Li CC, Geng YT, Zhou L, et al. Emodin protects rat liver from $\mathrm{CCI}(4)$ - induced fibrogenesis via inhibition of hepatic stellate cells activation. World J Gastroenterol. 2009:15:4753-62.

117. Schepartz Al, Subers NH. Catalase in honey. J Apic Res. 1996:5:37-43. 
118. Subrahmanyam M. Addition of antioxidant and polyethylene glycol 4000 enhances the healing property of honey in burns. Ann Burns Fire Disasters. 1996:9:93-5

119. Brady NF, Molan PC, Harfoot CG. The sensitivity of dermatophytes to the antimicrobial activity of manuka honey and other honey. Pharm Sci. 1997;2:1-3.

120. Wahdan H. Causes of the antimicrobial activity of honey. Infection. 1998;26: 26-31.

121. Lu J, Carter DA, Turnbull L, Rosendale D, Hedderley D, Stephens J, et al. The Effect of New Zealand Kanuka, Manuka and Clover Honeys on Bacterial Growth Dynamics; and Cellular Morphology Varies According to the Species. PLoS ONE. 2013;8:55898.

122. Rufian-Henares JA, Morales FJ. Functional properties of melanoidins: In vitro antioxidant, antimicrobial and antihypertensive activities. Food Res Int. 2007; 40:995-1002.

123. Mavric E, Wittmann S, Barth G, Henle T. Identification and quantification of methylglyoxal as the dominant antibacterial constituent of Manuka (Leptospermum scoparium) honeys from New Zealand. Mol Nutr Food Res. 2008;52:483-9.

124. Kwakman PHS, teVelde AA, de Boer L, Spejer D, Vandenbroucke-Grauls CM, Zaat SA. How honey kills bacteria. FASEB J. 2010;24:2576-82.

125. Subrahmanyam M, Hemmady A, Pawar SG. The sensitivity to honey of multidrug-resistant Pseudomonas Aeruginosa from infected burns. Ann Burns Fire Disasters. 2003;16:84-6.

126. Abuharfeil N, Al-Oran R, Abo-Shehada M. The effect of bee honey on the proliferative activity of human B- and T-lymphocytes and the activity of phagocytes. Food Agric Immunol. 1999;11:169-77.

127. Tonks A, Cooper RA, Price AJ, Molan PC, Jones KP. Stimulation of TNF-alpha release in monocytes by honey. Cytokine. 2001;14:240-2.

128. Tonks AJ, Cooper RA, Jones KP, Blair S, Parton J, Tanks A. Honey stimulates inflammatory cytokine production from monocytes. Cytokine. 2003;21:242-7.

129. Molan PC. The evidence supporting the use of honey as a wound dressing. Int J Low Extrem Wounds. 2006;5:40-54.

130. Nakajima Y, Nakano Y, Fuwano S, Hayahi N, Kinoshita A, Miyahara M, et al. Effects of three types of Japanese honey on full thickness wound in mice. Evid Based Complement Alternat Med. 2013;2013:504537.

131. Gupta SS, Singh O, Bhagel PS, Moses S, Shukla S, Mathur RK. Honey dressing versus silver sulfadiazine dressing for wound healing in burn patients: a retrospective study. J Cutan Surg. 2011;4(3):183-7.

132. Jull $A B$, Rodgers $A$, Walker N. Honey as a topical treatment for wounds. Cochrane Database Syst Rev. 2008;4:CD005083.

133. Wasiak J, Cleland H, Campbell F. Dressings for superficial and partial thickness burns. Cochrane Database Syst Rev. 2008;8(4):CD002106.

134. Storm-Versloot MN, Vos CG, Ubbink DT, Vermeulen H. Topical silver for preventing wound infection. Cochrane Database Syst Rev. 2010;17(3): CD006478.

135. Subrahmanyam M. Honey impregnated gauze versus polyurethane film (OpSiteR) in the treatment of burns - a prospective randomised study. $\mathrm{Br} J$ Plast Surg. 1993;46:322-3.

136. Subrahmanyam M. Honey impregnated gauze versus amniotic membrane in the treatment of burns. Burns. 1994;20:331-3.

137. Subrahmanyam M. A prospective randomised clinical and histopathological study of superficial burn wound healing with honey and silver sulfadiazine. Burns. 1998;24:157-61.

138. Liu J, Lu Y-F, Zhang Y, Wu KC, Fan F, Klaassen CD. Oleanolic acid alters bile acid metabolism and produces cholestatic liver injury in mice. Toxicol Appl Pharmacol. 2013;272:10.1016.

139. Chin MP, Reisman SA, Bakris GL, O'Grady M, Linde PG, McCullough PA, et al. Mechanisms contributing to adverse cardiovascular events in patients with type 2 diabetes mellitus and stage 4 chronic kidney disease treated with bardoxolone methyl. Am J Nephrol. 2014;39:499-508.

140. Chow HH, Garland LL, Heckman-Stoddard BM, Hsu CH, Butler VD, et al. A pilot clinical study of resveratrol in postmenopausal women with high body mass index: effects on systemic sex steroid hormones. J Transl Med. 2014;12:223.

141. Lovera J, Ramos A, Devier D, Garrison V, Kovner B, Reza T, et al. Polyphenon $E$, non-futile at neuroprotection in multiple sclerosis but unpredictably hepatotoxic: Phase I single group and phase I| randomized placebocontrolled studies. J Neurol Sci. 2015;358:46-52.

142. Pillukat MH, Bester C, Hensel A, Lechtenberg M, Petereit F, Beckebaum S, et al. Concentrated green tea extract induces severe acute hepatitis in a 63year-old woman-a case report with pharmaceutical analysis. J Ethnopharmacol. 2014;155:165-70.
143. Vohra S, Cvijovic K, Boon H, Foster BC, Jaeger W, LeGatt D, et al. Study of natural health product reactions (SPNAR): Active surveillance of adverse events following the concurrent natural health product and prescription use in community pharmacies. PLoS One. 2012;7(9):e45196.

144. Bun SS, Ciccolini J, Bun H, Aubert C, Catalin J. Drug interactions of paclitaxe metabolism in human liver microsomes. J Chemother. 2003;15:266-74.

145. Sak K. Chemotherapy and dietary phytocemical agents. Chem Res Practice. 2012;2012:282570.

146. Shang W, Lu W, Han M, Qiao J. The interactions of anticancer agents with tea catechins: current evidence from preclinical studies. Anticancer Agents Med Chem. 2014;14:1343-50.

147. Wang CZ, Luo X, Zhang B, Song WX, Ni M, Mehendale S, et al. Notoginseng enhances anti-cancer effect of 5-fluorouracil on human colorectal cancer cells. Cancer Chemother Pharmacol. 2007;60:69-79.

148. Sen S, Sharma H, Singh N. Curcumin enhances Vinorelbine mediated apoptosis in NSCLC cells by the mitochondrial pathway. Biochem Biophys Res Commun. 2005:331:1245-52.

149. Boocock DJ, Faust GE, Patel KR, Schinas AM, Brown VA, Ducharme MP, et al. Phase I dose escalation pharmacokinetic study in healthy volunteers of resveratrol, a potential cancer chemopreventive agent. Cancer Epidemiol Biomarkers Prev. 2007;16:1246-52.

150. Chen CY, Chen FA, Wu AB, Hsu HC, Kang JJ, Cheng HW. Effect of hydroxypropyl- $\beta$-cyclodextrin on the solubility, photo stability and in vitro permeability of alkannin/shikonin enantiomers. Int J Pharm. 1996;141:171-8.

151. Xia H, Tang C, Gui H, Wang X, Qi J, Wang X, et al. Preparation, cellular uptake and angiogenic suppression of shikonin-containing liposomes in vitro and in vivo. Biosci Rep. 2013;33:e00020.

152. Olthof MR, Hollman PCH, Vree TB, Katan MB. Bioavailabilities of quercetin-3glucoside and quercetin-4'-glucoside do not differ in humans. J Nutr. 2000; 130:1200-3.

153. Kiesewetter H, Koscielny J, Kalus U, Vix JM, Petrini O, van Toor BS, et al. Efficacy of orally administered extract of red vine leaf AS 195 (folia vitis viniferae) in chronic venous insufficiency (stages I-II). A randomized, doubleblind, placebo-controlled trial. Arzneimittelforschung. 2000:50:109-17.

154. Erlund I, Kosonen T, Alfthan J, Mäenpää J, Pertunen K, Kenraali J, et al. Pharmacokinetics of quercetin from quercetin aglycone and rutin in healthy volunteers. Eur J Clin Pharmaol. 2000;56:545-53.

155. Lombardi G, Vannini S, Blasi F, Marcotullio MC, Dominici L, Villarini M, et al. In Vitro Safety/Protection Assessment of Resveratrol and Pterostilbene in a Human Hepatoma Cell Line (HepG2). Nat Prod Commum. 2015;10:1403-8.

156. Turner RS, Thomas RG, Craft S, van Dyck CH, Mintzer J, Reynolds BA, et al. A randomised double-blind, placebo controlled trial of resveratrol for Alzheimer disease. Neurology. 2015;85:1383-91.

157. van der Made SM, Plat J, Mensink RP. Resveratrol does not influence metabolic risk markers related to cardiovascular health in overweight and slightly obese subjects: a randomized, placebo-controlled crossover trial. PLoS One. 2015;10:e0118393.

158. Joe AK, Schnol-Sussman F, Bresailier RS, Abrams JA, Hibshoosh H, Cheung K, et al. Phase Ib Randomized, Double-Blinded, Placebo-Controlled, Dose Escalation Study of Polyphenon E in Patients with Barrett's Esophagus. Cancer Prev Res. 2015:8:1131-7.

159. Chen IJ, Liu CY, Chiu JP, Hsu CH. Therapeutic effect of high-dose green tea extract on weight reduction: A randomized, double-blind, placebocontrolled clinical trial. Clin Nutr. 2015; in press

160. Chow HH, Cai Y, Hamkim IA, Crowell JA, Shahi F, Brooks CA, et al. Pharmacokinetics and safety of green tea polyphenols after multiple-dose administration of epigallocatechin gallate and polyphenon $E$ in healthy individuals. Clin Cancer Res. 2003:9:3312-9.

161. Zhao H, Zhu W, Jia L, Sun X, Chen G, Zhao X, et al. Phase I study of topical epigallocatechin-3-gallate (EGCG) in patients with breast cancer receiving adjuvant radiotherapy. $\mathrm{Br} J$ Radiol. In press

162. Dostal AM, Samavat H, Bedell S, Trokelson C, Wang R, Swenson K, et al. The safety of green tea extract supplementation in postmenopausal women at risk for breast cancer: results of the Minnesota Green Tea Trial. Food Chem Toxicol. 2015;83:26-35.

163. Mdhluli MC, van der Horst G. The effect of oleanolic acid on sperm motion characteristics and fertility of male Wistar rats. Lab Anim. 2002;36:432-7.

164. Cheng AL, Hsu CH, Lin CH, et al. Phase I clinical trial of curcumin, a chemo preventative agent, in patients with high-risk or pre-malignant lesions. Anticancer Res. 2001;21:2895-900. 
165. Goeal A, Kunnumakkara AB, Aggarwal BB. Curcumin as 'Curemin': from kitchen to clinic. Biochem Pharmacol. 2008;75:787-809.

166. Jiao Y, Wilkinson J, Di X, Wang W, Hatcher H, Kock ND, et al. Curcumin, a cancer chemopreventive and chemotherapeutic agent, is a biologically active iron chelator. Blood. 2009;113:462-9.

167. Albreht A, Vovk I, Simonovska B. Addition of $\beta$-lactoglobulin produces water-soluble shikonin. J Agric Food Chem. 2012;60:10834-43.

168. Su L, Liu L, Wang Y, Yan G, Zhang Y. Long-term systemic toxicity of shikonin derivatives in Wistar rats. Pharm Biol. 2014;52:486-90.

169. Simon A, Traynor K, Santos K, Blaser G, Bode U, Molan P. Medical Honey for Wound Care-Still the 'Latest Resort'? Evid Based Complement Alternat Med. 2009;6:165-73.

Submit your next manuscript to BioMed Central and we will help you at every step:

- We accept pre-submission inquiries

- Our selector tool helps you to find the most relevant journal

- We provide round the clock customer support

- Convenient online submission

- Thorough peer review

- Inclusion in PubMed and all major indexing services

- Maximum visibility for your research

Submit your manuscript at www.biomedcentral.com/submit
Biomed Central 